\title{
Milestones as a Guide for Academic Career Development
}

Gregory H. Blake, MD, MPH; Rebecca K. Kemmet, MD; Justin Jenkins, DO; Robert E. Heidel, PhD; Garland A. Wilson, MD

BACKGROUND AND OBJECTIVES: Faced with a limited supply of applicants for faculty positions, increasing demands for residency faculty, and a growing number of programs, our program has increasingly filled ranks with recent residency graduates with broad scope but limited experience and training in academics. These early-career clinicians often require further mentorship as they seek advancement in clinical skills and development of teaching and scholarly activity skill sets.

METHODS: To educate our recent residency graduates in teaching/scholarly activity skills, and to provide a career trajectory, we created a process to guide their maturation with milestones using the six core competencies from the Accreditation Council for Graduate Medical Education. The milestones consist of four levels of clinician/academician maturation. Each competence has goals and activities for each level of development. We validated the milestones using our physician faculty assessing time spent in academic medicine and academic rank.

RESULTS: Faculty of higher academic rank scored higher in all competencies than faculty of lower academic rank. Correlation between systems-based practice and years in academics demonstrated statistical significance, and all other categories showed nonsignificant associations.

CONCLUSIONS: The milestones are consistent with faculty academic development and career progression, and may serve as a guide for career advancement and as a guideline for professional progression for residency clinicians. Further testing for validation in other family medicine programs is necessary, but preliminary findings indicate this milestone project may be of service to our profession.

(Fam Med. 2019;51(9):760-5.)

doi: 10.22454/FamMed.2019.109290

$\mathbf{W}$ ith the increasing number of new medical schools, new family medicine residency programs, and current faculty retirements, there is a need for new physicians possessing broad-based clinical skill sets. ${ }^{1}$ A clearly defined career path in academic medicine to guide new physicians' development is often lacking.

This raises the question of how to develop teaching/scholarly activity skill sets in faculty members. We chose to model professional growth in academic medicine after the educational milestones created to measure and report the growth of residents as part of the Next GME Accreditation System authored by the Accreditation Council for Graduate Medical Education (ACGME). The milestones the residents reached provided meaningful data on the performance graduates achieved before entering unsupervised practice. ${ }^{2}$

Academic medicine utilizes milestones for several functions. Shah and colleagues developed a series of educational milestones for surgery residents to evaluate their faculty. The residents reported the milestones were easier, more effective, and objective in evaluating them. ${ }^{3}$ Garand and colleagues utilized milestones to guide nurses through the promotion and tenure process. The tool prioritized the critical milestones necessary for promotion by offering a time frame to accomplish them. ${ }^{4}$ Srinivasan and colleagues identified six core competencies and four specialized competencies for educators. They adapted skills for medical educators from the physician competencies authored by the ACGME and the roles from the Royal College's Canadian Medical Education Directives. This tool helps educators think about the skill sets and resources needed for success in their

From the Department of Family Medicine (Drs Blake, Kemmet, Jenkins, and Wilson) and Department of Surgery (Dr Heidel), University of Tennessee Graduate School of Medicine, Knoxville, TN. 
chosen field. ${ }^{5}$ Görlitz and colleagues created six educational competencies with 57 learning objectives. The model maps faculty development initiatives at different sites within their system. The core competencies for medical educators outlines a profile of requirements for teachers. ${ }^{6}$

Our study sought to assess the ability of our faculty milestone form to guide a faculty member's development. To internally validate its ability to measure growth, all physician members of the department completed the form. Our institutional review board reviewed this study and granted an exception from formal review.

\section{Methods}

Our milestones identify four levels of progression in an academic physician's career (Table 1). Under each of the six core competency categories are activities common in an academic physician's job description that may meet this level of accomplishment (Table 2). The ideal firsttime faculty member would possess broad generalist skill sets, perform several procedures, and provide hospital care. The level one milestones highlight this proforma, combining
ACGME Milestones levels three and four. Level two faculty milestones feature teaching the level one skills and adding scholarly activity pursuits. The level three faculty milestones feature leadership positions and advanced scholarly activity. Faculty level four milestones target national recognition activities. Faculty members may score at a higher level of milestone on specific competencies as they advance in years of service in academic settings by obtaining more exposure, experience, and the availability of leadership opportunities.

Frequency and descriptive statistics tested the sample by academic rank and years of academic experience. Skewness and kurtosis statistics checked for the statistical assumption of normality for each milestone's distribution. If either statistic was 2.0, then Levene's Test of Equality of Variances tested for homogeneity of variance. When statistical assumptions were violated, nonparametric Kruskal-Wallis tests evaluated for significant effects associated with academic rank across the milestones. We used post hoc pairwise Mann-Whitney $U$ tests when a significant main effect was found. We reported medians and interquartile ranges and interpreted for the nonparametric analyses. We used Spearman's $\rho$ correlation to analyze the associations between years of academic experience and the six milestones.

\section{Results}

The statistical assumptions of normality and homogeneity of variance were violated for each milestone outcome, so nonparametric analyses were conducted. Nonsignificant main effects were found between the academic rank groups for all except for systemic practice, for which a significant main effect was detected. Post hoc testing found statistically significant differences between assistant professors and associate professors, assistant professors and professors, but not for associate professors and professors (Table 3). Spearman's $\rho$ correlation found a statistically significant association between systematic practice and years of academic experience, and nonsignificant associations between all other categories (Table 4).

Table 1: Years in Academic Medicine

Current Academic Appointment

\begin{tabular}{|c|c|c|c|c|}
\hline & Level 1 & Level 2 & Level 3 & Level 4 \\
\hline 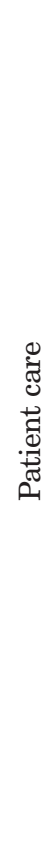 & $\begin{array}{l}\text { - Coordinates care for } \\
\text { patients requiring } \\
\text { urgent/emergent } \\
\text { - } \text { medical care } \\
\text { - Apply clinical } \\
\text { guidelines in the } \\
\text { treatment of patients } \\
\text { and facilitates their } \\
\text { efforts in managing } \\
\text { chronic conditions } \\
\text { - Use shared decision- } \\
\text { making in explaining } \\
\text { health promotion and } \\
\text { disease prevention } \\
\text { recommendations to } \\
\text { patients/families } \\
\text { - Link patients with } \\
\text { community resources } \\
\text { to achieve health } \\
\text { promotion goals } \\
\text { - Address psychosocial } \\
\text { implications on acute } \\
\text { and chronic medical } \\
\text { problems }\end{array}$ & $\begin{array}{l}\text { - Teach learners to } \\
\text { coordinate the care of } \\
\text { acutely ill patients with } \\
\text { consulting services } \\
\text { - Lead clinical care teams } \\
\text { in ambulatory and } \\
\text { inpatient settings } \\
\text { - Teach learners to } \\
\text { manage patients with } \\
\text { chronic disease and } \\
\text { comorbidities } \\
\text { - Teach learners disease } \\
\text { prevention and health } \\
\text { promotion } \\
\text { - Write a case report for } \\
\text { publication } \\
\text { - Learn new procedural/ } \\
\text { clinical skill }\end{array}$ & $\begin{array}{l}\text { - Teach learners through } \\
\text { role modeling the } \\
\text { integration of the } \\
\text { clinical practice with } \\
\text { community data to } \\
\text { improve population } \\
\text { health } \\
\text { - Expand medical acumen } \\
\text { into new arenas filling } \\
\text { voids in learners } \\
\text { knowledge } \\
\text { - Expand skills and teach } \\
\text { others } \\
\text { - Present podium } \\
\text { presentation/workshop } \\
\text { in national or regional } \\
\text { venue }\end{array}$ & $\begin{array}{l}\text { - Lead patient care } \\
\text { teams into rural, } \\
\text { mission field, inner } \\
\text { city or other settings/ } \\
\text { activities to improve } \\
\text { care for patients } \\
\text { lacking access } \\
\text { - Present a keynote } \\
\text { podium presentation } \\
\text { or workshop } \\
\text { in national or } \\
\text { international venue }\end{array}$ \\
\hline
\end{tabular}


Table 1, Continued

\begin{tabular}{|c|c|c|c|c|}
\hline & Level 1 & Level 2 & Level 3 & Level 4 \\
\hline 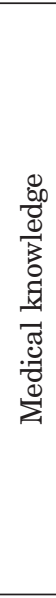 & $\begin{array}{l}\text { - Achieve ABFM board } \\
\text { certification }\end{array}$ & $\begin{array}{l}\text { - Maintain ABFM } \\
\text { certification } \\
\text { - Write a review article for } \\
\text { publication or a book } \\
\text { chapter } \\
\text { - Demonstrate ability } \\
\text { to effectively convey } \\
\text { medical knowledge to } \\
\text { learners } \\
\text { - Present a poster at a } \\
\text { conference } \\
\text { - Present/lead a topic/ } \\
\text { workshop at a } \\
\text { conference }\end{array}$ & $\begin{array}{l}\text { - Develop local practice } \\
\text { guidelines } \\
\text { - Serve as a reviewer for } \\
\text { medical journals }\end{array}$ & $\begin{array}{l}\text { - } \text { Author a medical book } \\
\text { - } \text { Serve as editor of } \\
\text { textbook } \\
\text { - } \text { Participate in national } \\
\text { guideline setting } \\
\text { panels } \\
\text { - Be invited to comment } \\
\text { in national press on } \\
\text { areas of expertise } \\
\text { - Chair a national } \\
\text { medical organization } \\
\text { - Serve on national } \\
\text { educational } \\
\text { committee } \\
\text { - Direct national } \\
\text { meetings or } \\
\text { conferences } \\
\end{array}$ \\
\hline 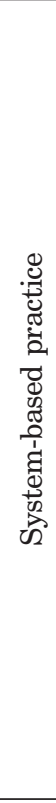 & $\begin{array}{l}\text { - Analyze personal and } \\
\text { systemic causes } \\
\text { of medical errors } \\
\text { common to family } \\
\text { medicine } \\
\text { - } \quad \text { Partner with patients } \\
\text { to increase efficiency } \\
\text { and effectiveness in } \\
\text { patient care being } \\
\text { conscious of resource } \\
\text { use and cost in your } \\
\text { practice } \\
\text { - Use team-based care to } \\
\text { provide accountable } \\
\text { and coordinated care } \\
\text { to meet patient needs } \\
\text { Demonstrate } \\
\text { knowledge of billing } \\
\text { and the health } \\
\text { insurance system and } \\
\text { its effect on patients } \\
\text { Participate in a roots } \\
\text { cause analysis } \\
\end{array}$ & $\begin{array}{l}\text { - Lead ambulatory and } \\
\text { inpatient teams } \\
\text { in using resources } \\
\text { efficiently and cost } \\
\text { conscientiously in } \\
\text { complex cases } \\
\text { - Serve on a hospital } \\
\text { committee } \\
\text { - Serve on an academic } \\
\text { committee at own } \\
\text { facility } \\
\text { - Lead a QI project in your } \\
\text { program } \\
\text { - Lead a roots cause } \\
\text { analysis } \\
\text { Teach seamless } \\
\text { transitions of care }\end{array}$ & $\begin{array}{l}\text { - Serve as a director of } \\
\text { a division (PreDoc, } \\
\text { Residency, Research, } \\
\text { Clinical) within } \\
\text { department } \\
\text { - Serve as officer or } \\
\text { delegate to local or } \\
\text { state professional } \\
\text { organization } \\
\text { - Serve as chairman of } \\
\text { committee within } \\
\text { educational system or } \\
\text { medical center }\end{array}$ & $\begin{array}{l}\text { - Serve as delegate, } \\
\text { officer, or chairman } \\
\text { of a national or } \\
\text { international } \\
\text { organization } \\
\text { - Serve as consultant } \\
\text { to national or } \\
\text { international } \\
\text { committees } \\
\text { - Serve as chair of an } \\
\text { academic department } \\
\text { - Serve as a member } \\
\text { of clinical/ } \\
\text { multidisciplinary } \\
\text { national committees } \\
\text { academically or } \\
\text { clinically }\end{array}$ \\
\hline 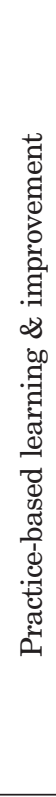 & $\begin{array}{l}\text { - Demonstrate critical } \\
\text { appraisal of research } \\
\text { using set criteria } \\
\text { - } \quad \text { Analyze personal } \\
\text { development as a } \\
\text { physician and use } \\
\text { a learning plan to } \\
\text { advance skills } \\
\text { - Initiate quality } \\
\text { improvement project } \\
\text { in clinical endeavor } \\
\text { - Principles of evidence- } \\
\text { based care and } \\
\text { information mastery } \\
\text { are foundation of } \\
\text { clinical practice }\end{array}$ & $\begin{array}{l}\text { - Design, perform, and } \\
\text { analyze a case-control } \\
\text { study } \\
\text { - Design/lead a journal } \\
\text { club on critical } \\
\text { appraisal of medical } \\
\text { literature } \\
\text { - Manage quality } \\
\text { improvement for a } \\
\text { clinical entity } \\
\text { - Supervise/direct quality } \\
\text { improvement initiatives } \\
\text { for learners }\end{array}$ & $\begin{array}{l}\text { Design, perform, and } \\
\text { analyze prospective } \\
\text { studies (double-blind, } \\
\text { controlled) } \\
\text { - Create protocols for } \\
\text { continuous review of } \\
\text { practice procedures } \\
\text { and outcomes in } \\
\text { department or medical } \\
\text { community } \\
\text { - Strive through clinical } \\
\text { systemic activities to } \\
\text { improve the patient } \\
\text { experience of care, } \\
\text { improve the health of } \\
\text { populations, and reduce } \\
\text { the cost of health care } \\
\text { - Submit and receive } \\
\text { funding for a research } \\
\text { project } \\
\text { Construct a faculty } \\
\text { development } \\
\text { curriculum/seminar }\end{array}$ & $\begin{array}{l}\text { Design, perform, } \\
\text { and analyze meta- } \\
\text { analyses on medical } \\
\text { topics } \\
\text { - Maintain R01or } \\
\text { similar sources of } \\
\text { grant funding } \\
\text { - Manage quality } \\
\text { improvement for } \\
\text { multiple clinical } \\
\text { entities in an } \\
\text { organization }\end{array}$ \\
\hline
\end{tabular}


Table 1, Continued

\begin{tabular}{|c|c|c|c|c|}
\hline & Level 1 & Level 2 & Level 3 & Level 4 \\
\hline 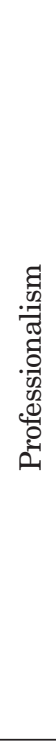 & $\begin{array}{l}\text { - Fulfill the professional } \\
\text { obligations/ } \\
\text { responsibilities of a } \\
\text { family physician } \\
\text { - Model professional } \\
\text { personal behavior } \\
\text { exhibiting self- } \\
\text { awareness, self- } \\
\text { management, } \\
\text { social awareness } \\
\text { and relationship } \\
\text { management } \\
\text { Demonstrate value for } \\
\text { a patient's beliefs, } \\
\text { mores, and cultural } \\
\text { practices in shared } \\
\text { understanding of } \\
\text { patient care plans } \\
\text { Recognize problems } \\
\text { and seek to find } \\
\text { solutions }\end{array}$ & $\begin{array}{l}\text { - Develop a shared } \\
\text { appreciation of } \\
\text { learner and work in } \\
\text { partnership to meet } \\
\text { their personal and } \\
\text { professional goals } \\
\text { - Demonstrate ability to } \\
\text { work effectively with } \\
\text { faculty in meeting } \\
\text { department/residency/ } \\
\text { institutional goals } \\
\text { - Serve as a mentor for } \\
\text { learners }\end{array}$ & $\begin{array}{l}\text { - Demonstrate a high-level } \\
\text { of ethics in working } \\
\text { with the media, } \\
\text { representatives of } \\
\text { regulatory bodies, and } \\
\text { the government } \\
\text { - Demonstrate a high- } \\
\text { level of ethics and } \\
\text { understanding in } \\
\text { professional/personal } \\
\text { relationships with } \\
\text { colleagues } \\
\text { - Serve as mentor for } \\
\text { faculty }\end{array}$ & 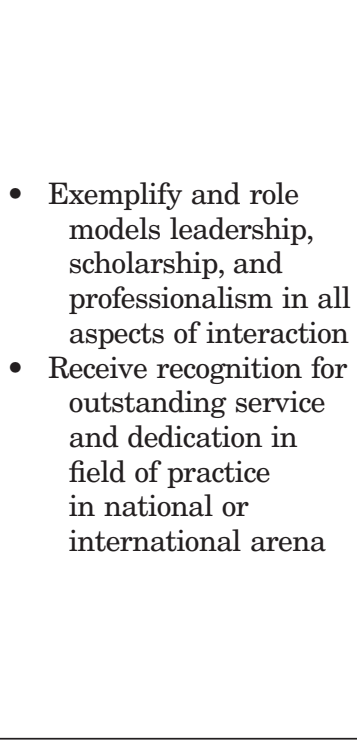 \\
\hline & $\begin{array}{l}\text { - Demonstrate respect } \\
\text { for a patient's } \\
\text { autonomy in their } \\
\text { health decisions } \\
\text { - Deliver difficult } \\
\text { information regarding } \\
\text { personal health } \\
\text { issues empathetically } \\
\text { and effectively } \\
\text { - Use Electronic } \\
\text { Health Record in } \\
\text { communicating with } \\
\text { health care team } \\
\text { - Demonstrate effective } \\
\text { and ethical use of } \\
\text { communication } \\
\text { systems } \\
\text { Deliver information to } \\
\text { fellow members of the } \\
\text { academic community } \\
\text { empathetically and } \\
\text { effectively using } \\
\text { multiple forms of } \\
\text { communication }\end{array}$ & $\begin{array}{l}\text { - Build effectively rapport } \\
\text { with learners in a } \\
\text { clinical environment } \\
\text { - Present didactic } \\
\text { information in small } \\
\text { group and lecture } \\
\text { formats demonstrating } \\
\text { recognition of learning } \\
\text { style of students/ } \\
\text { residents/ clinicians } \\
\text { - Demonstrate ability } \\
\text { to lead a team in } \\
\text { ambulatory or inpatient } \\
\text { settings that fosters } \\
\text { trust, respect, and } \\
\text { understanding }\end{array}$ & $\begin{array}{l}\text { - Work well with } \\
\text { difficult learners and } \\
\text { develop remediation } \\
\text { plans which may } \\
\text { accomplish learner and } \\
\text { institutional goals } \\
\text { - Recognize and utilize } \\
\text { the principles of } \\
\text { conflict management in } \\
\text { difficult situations } \\
\text { - Demonstrate success } \\
\text { in managing change } \\
\text { at the department/ } \\
\text { institutional level }\end{array}$ & $\begin{array}{l}\text { - Demonstrate } \\
\text { leadership in } \\
\text { cultural proficiency, } \\
\text { understanding of } \\
\text { health disparities, } \\
\text { and social } \\
\text { determinants of } \\
\text { health in national/ } \\
\text { international } \\
\text { situations } \\
\text { - Excel in conflict } \\
\text { management and in } \\
\text { de-escalating difficult } \\
\text { situations }\end{array}$ \\
\hline
\end{tabular}

Table 2: Academic Milestones

\begin{tabular}{|c|c|c|c|c|}
\hline Development Criteria & Level 1 & Level 2 & Level 3 & Level 4 \\
\hline Goals for growth & $\begin{array}{l}\text { - Solidify clinical } \\
\text { skill sets } \\
\text { - Develop teaching } \\
\text { skill sets }\end{array}$ & $\begin{array}{l}\text { - Establish niche in } \\
\text { program } \\
\text { - Develop skill sets } \\
\text { in research/ } \\
\text { other scholarly } \\
\text { activities }\end{array}$ & $\begin{array}{l}\text { - Hone leadership } \\
\text { skills }\end{array}$ & $\begin{array}{l}\text { - Network/influence } \\
\text { - Clinical medicine } \\
\text { - Academic medicine }\end{array}$ \\
\hline Academic rank & Assistant professor & $\begin{array}{l}\text { Assistant/early } \\
\text { associate professor }\end{array}$ & $\begin{array}{l}\text { Associate professor/ } \\
\text { early professor }\end{array}$ & Professor \\
\hline $\begin{array}{l}\text { Time devoted to } \\
\text { academics (years) }\end{array}$ & $1-3$ & $4-7$ & $8-15+$ & $16+$ \\
\hline
\end{tabular}


Table 3: Descriptive Statistics for Kruskal-Wallis Tests

\begin{tabular}{|l|c|c|c|c|}
\hline \multicolumn{1}{|c|}{ Milestone } & Assistant Professor* & Associate Professor* & Professor* $^{*}$ & $\boldsymbol{P}^{*}$ Value \\
\hline Patient care & $3.0(0.0)$ & $3.5(1.0)$ & $3.0(0.8)$ & .37 \\
\hline Medical knowledge & $2.0(0.0)$ & $3.0(0.8)$ & $2.5(1.0)$ & .57 \\
\hline Systematic practice & $2.0(0.0)$ & $2.0(0.0)$ & $3.0(0.8)$ & .01 \\
\hline Practice/learn/improve & $2.0(0.0)$ & $3.0(1.5)$ & $1.0(1.5)$ & .30 \\
\hline Professionalism & $2.0(0.0)$ & $3.5(1.0)$ & $3.5(1.0)$ & .42 \\
\hline Communication & $2.0(0.0)$ & $3.5(1.0)$ & $3.5(1.0)$ & .09 \\
\hline
\end{tabular}

* Values are median (interquartile range).

** $P<.05$.

Table 4: Spearman Correlations Between Milestones and Years of Experience

\begin{tabular}{|l|c|}
\hline \multicolumn{1}{|c|}{ Milestone } & Correlation With Years of Academic Experience \\
\hline Patient care & 0.39 \\
\hline Medical knowledge & 0.29 \\
\hline Systematic practice & $0.86^{*}$ \\
\hline Practice/learn/improve & -0.59 \\
\hline Professionalism & 0.35 \\
\hline Communication & 0.48 \\
\hline
\end{tabular}

* $P<0.05$.

\section{Discussion}

This academic milestone form effectively describes our department's strengths and weaknesses along with anticipated development trends in the other competencies. This department's footprint maintains high inpatient and outpatient profile, which is consistent with faculty scoring higher in patient care, professionalism, and communication categories across years in academic medicine and academic rank categories. The accelerated performance of assistant and associate professors in medical knowledge and practice improvement is likely related to six of the seven faculty in these ranks having completed academic fellowships compared to $59 \%$ for full professors (Table 5).
This department's profile is likely unique to programs with similar academic/clinical environments. A program's profile would differ by the health care system's emphasis on clinical, teaching or research pursuits and whether they reside on a medical school campus, or are a stand-alone community residency.

The limitations of this study limit generalizability. The total number of faculty evaluated was small. Further, all participants were located at the same site, and each author participated.

Our milestones provide a matrix whereby academic programs can guide professional development. These guidelines are not intended as a checklist for academic promotion or as a framework for evaluations.
They are not intended to bring about punitive measures, but offer insight on career trajectory. Based on personal characteristics and skills, physicians gravitate toward the levels of their interest and expertise. For this reason, these guidelines should not function as a plumb line to evaluate individual success or serve to define a productive academic career.

The Milestones Form should be tested in other family medicine programs to determine generalizability, its ability to define strengths/weaknesses, and gauge faculty members' development. If these are realized the form could guide faculty selection, enhance faculty member's strengths while minimizing weaknesses, and nurture the development of faculty within departments. 
Table 5: Department of Family Medicine

\begin{tabular}{|c|c|c|c|}
\hline \multicolumn{4}{|c|}{ Demographics } \\
\hline & Assistant Professor & Associate Professor & Professor \\
\hline Age (years) & $31,34,37$ & $48,50,61,66$ & $49,65,67,69$ \\
\hline $\begin{array}{l}\text { Gender } \\
\text { Male } \\
\text { Female }\end{array}$ & $\begin{array}{l}2 \\
1 \\
\end{array}$ & $\begin{array}{l}3 \\
1 \\
\end{array}$ & $\begin{array}{l}3 \\
1 \\
\end{array}$ \\
\hline Academic fellowship & 3 & 3 & 2 \\
\hline Publications & 5 & 9 & 5 \\
\hline $\begin{array}{l}\text { Presentations } \\
\text { (regional, national) }\end{array}$ & 8 & 4 & 8 \\
\hline \multicolumn{4}{|c|}{ Clinical Practice } \\
\hline \multicolumn{4}{|c|}{$\begin{array}{l}\text { University family physicians } \\
\text { University occupational medicine service } \\
\text { University family physicians inpatient service } \\
\text { University sports medicine clinic } \\
\text { Wound care clinic }\end{array}$} \\
\hline \multicolumn{4}{|c|}{ Academic Programs } \\
\hline & & \multicolumn{2}{|c|}{ Learners/Year } \\
\hline \multicolumn{2}{|c|}{ Family medicine residency program } & \multicolumn{2}{|c|}{$8-8-8$} \\
\hline Sports medicine fellor & & \multicolumn{2}{|c|}{1} \\
\hline \multicolumn{2}{|c|}{ Emergency medicine fellowship } & \multicolumn{2}{|c|}{2} \\
\hline \multicolumn{2}{|l|}{ M3 clerkship } & \multicolumn{2}{|c|}{18} \\
\hline \multicolumn{2}{|l|}{ M4 elective } & \multicolumn{2}{|c|}{9} \\
\hline
\end{tabular}

ACKNOWLEDGMENTS: The authors thank Mack Worthington, MD for his counsel on the Milestone form and Ms Diane Jones for her preparation of the manuscript.

CORRESPONDING AUTHOR: Address correspondence to Dr Gregory Blake, University of Tennessee Knoxville Graduate School of Medicine - Family Medicine, 1924 Alcoa Highway, Knoxville, TN 37920-1511. 865-305-5056. ghblake@utmck.edu.

\section{References}

1. Petterson SM, Rayburn WF, Liaw WR. When do primary care physicians retire? Implications for workforce projections. Ann Fam Med. 2016;14(4):344-349
2. Nasca TJ, Philibert I, Brigham T, Flynn TC. The Next GME Accreditation System- rationale and benefits. N Engl J Med. 2012;366(11):1051 1056.

3. Shah D, Goettler CE, Torrent DJ, et al. Milestones: The Road to Faculty Development. J Surg Educ. 2015;72(6):e226-e235

4. Garand L, Matthews JT, Courtney KL, et al. Development and use of a tool to guide junior faculty in their progression toward promotion and tenure. J Prof Nurs. 2010;26(4):207-213.

5. Srinivasan M, Li ST, Meyers FJ, et al. "Teaching as a Competency": competencies for medical educators. Acad Med. 2011;86(10):12111220
6. Görlitz A, Ebert T, Baver D, Grast M, Hofer M, Lammerding-Köppel M, Fabry G. Core Competencies for Medical Teachers (KLM). A position paper of the GMA Committee on Personal and Organizational Development in Teaching. GMS Zeitschrift für Medizinische Austiktung. 2015;32(2);1/14-7/14. 